ROCZNIKI HUMANISTYCZNE

Tom LXVIII, zeszyt $6-2020$

DOI: http://dx.doi.org/10.18290/rh20686-9

WIKTOR PSKIT

\title{
JĘZYK LITURGICZNY ORDYNARIATÓW PERSONALNYCH DLA BYŁYCH ANGLIKANÓW. ZARYS OGÓLNY
}

\section{WPROWADZENIE ${ }^{1}$}

Celem niniejszej publikacji jest przybliżenie polskojęzycznemu czytelnikowi ${ }^{2}-\mathrm{z}$ uwagi na ograniczone rozmiary artykułu, w ogólnym zarysie głównych cech językowych tekstów liturgicznych Ordynariatów Personalnych dla byłych anglikanów. Teksty te są zamieszczone w zaaprobowanej przez Stolicę Apostolską księdze liturgicznej zatytułowanej Divine Worship: The Missal (dosł. Kult Boży: Mszal), która weszła do użytku liturgicznego począwszy od Adwentu 2015 r. Niniejsze opracowanie dotyczy zatem podtypu języka religijnego, jakim niewątpliwie jest język liturgii, w kontekście obrzędów wspólnot, które niedawno powróciły do jedności z Rzymem. Choć w sensie ilościowym wspólnoty te znajdują się na swego rodzaju marginesie, czy - posługując się modnym określeniem papieża Franciszka - wręcz peryferium w Kościele rzymsko-katolickim, to właściwości językowe liturgii Ordynariatów mogą zainteresować badaczy języka z uwagi na to, że ilustrują jeden z kilku trendów kształtujących oblicze językowe współczesnej liturgii

Dr WIKTOR PSKIT - adiunkt w Instytucie Anglistyki Uniwersytetu Łódzkiego; adres do korespondencji - email: wiktor.pskit@uni.lodz.pl; ORCID: https://orcid.org/0000-0003-2786-4741.

${ }^{1}$ Część omawianych w niniejszym opracowaniu zagadnień została przedstawiona w formie referatów na konferencjach: Benedykt XVI i liturgia (Toruń 2017) oraz Język religijny dawniej i dziś (w kontekście teologicznym i kulturowym) (Poznań 2018). Autor pragnie podziękować organizatorom tych wydarzeń za możliwość przedstawienia wyników swoich dociekań, a uczestnikom konferencji za wnikliwe komentarze i uwagi do przedstawionych przez siebie tez. Jednocześnie przedstawiony tu materiał stanowi część znajdującego się w przygotowaniu obszerniejszego studium dotyczącego użycia angielszczyzny we współczesnej liturgii rzymskiej.

${ }^{2} \mathrm{O}$ ile istnieją polskojęzyczne opracowania, głównie na gruncie teologicznym, dotyczące Ordynariatów Personalnych, to autorowi niniejszego tekstu nie są znane żadne publikacje w języku polskim poruszające kwestie języka liturgii Ordynariatów. 
rzymskiej. Poniżej postaramy się pokazać, że w przypadku mszału Divine Worship mamy do czynienia z językiem narodowym o wysokim stopniu hieratyczności, co łatwo zauważyć, zestawiając te teksty z ich odpowiednikami w angielskim przekładzie Mszału Rzymskiego (2010). Analizowany poniżej materiał językowy nie był do tej pory przedmiotem badań językoznawczych, a dostępne publikacje to mające raczej fragmentaryczny charakter opracowania duchownych bądź świeckich członków Ordynariatów, w tym liturgistów zaangażowanych w prace watykańskiej komisji przygotowującej mszał Divine Worship. Jest to zrozumiałe, po pierwsze - ze względu na ograniczony zasięg działania Ordynariatów i ich liturgii, a po drugie - ze względu na „świeżość" samych tekstów (w użytku liturgicznym od końca 2015r.).

\section{ORDYNARIATY PERSONALNE: TŁO HISTORYCZNE}

Ordynariaty Personalne dla anglikanów pragnących powrócić do pełnej jedności z Rzymem zostały ustanowione na mocy konstytucji apostolskiej Benedykta XVI Anglicanorum coetibus (2009). Rzecz jasna, indywidualne konwersje anglikanów na katolicyzm miały miejsce już znacznie wcześniej. Tym, co nadaje dokumentowi z roku 2009 szczególny charakter, jest umożliwienie anglikańskim wspólnotom konwersji grupowych. Ordynariat jest definiowany w paragrafie 4 Anglicanorum coetibus w następujący sposób:

Ordynariat składa się z wiernych świeckich, duchowieństwa oraz członków Instytutów Życia Konsekrowanego i Stowarzyszeń Życia Apostolskiego, pierwotnie należących do Wspólnoty Anglikańskiej, a obecnie znajdujących się w pełnej komunii z Kościołem katolickim, albo tych, którzy otrzymują sakramenty inicjacji chrześcijańskiej w obrębie jurysdykcji Ordynariatu.

Jednak na szczególne podkreślenie w kontekście niniejszego opracowania zasługuje punkt III paragrafu 5:

Nie wykluczając celebracji liturgicznych według Rytu Rzymskiego, Ordynariat może sprawować Najświętszą Eucharystię oraz inne sakramenty, Liturgię Godzin oraz inne celebracje liturgiczne według ksiąg liturgicznych właściwych tradycji anglikańskiej, zatwierdzonych przez Stolicę Apostolską, aby w obrębie Kościoła katolickiego zachować tradycje liturgiczne, duchowe i duszpasterskie Wspólnoty Anglikańskiej jako cenny dar, karmiący wiarę członków Ordynariatu oraz skarb, którym można się dzielić z innymi. 
Przywołane sformułowanie zakłada zachowanie przez Ordynariaty specyficznych dla anglikanizmu elementów obrzędowych, w tym - jak się przekonamy poniżej - językowych. Co więcej, ,przeszczepienie” tych tradycji liturgicznych ma się przyczynić do ubogacenia liturgii Kościoła w ogólności.

Obecnie funkcjonują trzy struktury kościelne powołane na podstawie konstytucji Anglicanorum coetibus, odpowiednio w Wielkiej Brytanii, Ameryce Północnej (Stany Zjednoczone i Kanada) oraz w Australii i Oceanii:

(1) Ordynariat Personalny Matki Bożej z Walsingham (dla byłych członków Kościoła Anglii i Kościoła Walii), powołany w roku 2011

(2) Ordynariat Personalny Katedry św. Piotra (dla byłych członków Kościoła Episkopalnego lub innych Kościołów tradycji anglikańskiej i metodystycznej w Stanach Zjednoczonych i Kanadzie), utworzony w roku $2012^{4}$

(3) Ordynariat Personalny Matki Bożej Krzyża Południa (dla byłych członków Kościoła Anglikańskiego Australii), powołany w roku $2012^{5}$.

Choć w skali Kościoła katolickiego Ordynariaty mają ograniczony charakter, struktury te działają dosyć prężnie na polu duszpasterskim, a jak wskazują źródła internetowe, bywa, że liturgia sprawowana przez duchownych Ordynariatów przyciąga katolików spoza tych post-anglikańskich wspólnot ${ }^{6}$.

\section{MSZAŁ DIVINE WORSHIP I JEGO ŹRÓDŁA}

Na płaszczyźnie ogólnej pod względem językowym i obrzędowym liturgia Ordynariatów jest reprezentatywna dla zwyczajów liturgicznych nurtu określanego $\mathrm{w}$ anglikanizmie mianem anglo-katolicyzmu, utożsamianego także z tzw. Kościołem Wysokim ${ }^{7}$. Sam język Divine Worship: The Missal bywa określany jako tzw. Prayer Book English, czyli angielszczyzna Modlitewnika Powszechnego. Jest to wysoce zarchaizowana odmiana języka angielskiego zawierająca dużą ilość elementów obecnych w pierwszych wydaniach Modlitewnika Powszechnego. Historycznie czerpie ona zatem z angielszczyz-

\footnotetext{
${ }^{3}$ ordinariate.co.uk/ (dostęp: 01.07.2019).

${ }^{4}$ ordinariate.net/ (dostęp: 01.07.2019).

${ }^{5}$ www.ordinariate.org.au/ (dostęp: 01.07.2019).

${ }^{6}$ Por. artykuły w czasopiśmie The Portal Magazine wydawanym przez Ordynariat Matki Bożej z Walsingham, wersja elektroniczna dostępna na stronie: www.portalmag.co.uk/read.html. Dostęp 01.07.2019.

${ }^{7} \mathrm{O}$ niejednolitym charakterze wspólnoty anglikańskiej i współczesnych podziałach w jej łonie w języku polskim piszą m.in. Kantyka i Składanowski.
} 
ny XVI-wiecznej i stąd niektórzy używają określeń typu angielszczyzna szekspirowska, angielszczyzna elżbietańska czy angielszczyzna Tudorów ${ }^{8}$.

Opracowaniem tekstów liturgicznych dla Ordynariatów zajęła się międzydykasterialna komisja Anglicanae traditiones utworzona w 2011 r. przez Kongregację Nauki Wiary oraz Kongregację Kultu Bożego i Dyscypliny Sakramentów. Owocem prac tejże komisji są dwie księgi liturgiczne: jedna zawierająca obrzędy sakramentów chrztu i małżeństwa oraz obrzędy pochówku (Divine Worship: Occasional Services (2014)) oraz mszał (Divine Worship: The Missal (2015)). Mszał wszedł do użytku liturgicznego począwszy od adwentu 2015 r. Wypada podkreślić, że pracom wspomnianego ciała przygotowującego księgi liturgiczne dla Ordynariatów przyświecał wyżej cytowany zapis konstytucji Anglicanorum coetibus wskazujący na możliwość uwzględnienia w liturgii byłych anglikanów elementów „właściwych tradycji anglikańskiej”.

Prymarnym źródłem tekstów dla Divine Worship: The Missal są, jak to ujmuje Burnham (Divine 160), teksty liturgiczne reformacji angielskiej, w tym wspomniany już Modlitewnik Powszechny (Book of Common Prayer), którego powstanie zainspirowała schizma anglikańska. Pierwsze wydanie Modlitewnika Powszechnego ukazało się w roku 1549 i było wynikiem pracy translatorskiej i edytorskiej Thomasa Cranmera, arcybiskupa Canterbury. Później wydawano kolejne poprawione wersje tej księgi, a najbardziej trwałą okazała się poprawka z roku 1662, która pozostaje głównym oficjalnie zaaprobowanym tekstem liturgicznym anglikanizmu, choć współcześnie, na początku XXI wieku, w dużej mierze zastąpiła ją alternatywna księga Common Worship (dosł. Wspólne wielbienie) (Patterson, Burnham Contribution). Jedną z ksiąg, którymi posługiwała się komisja Anglicanae Traditiones, był swoisty prekursor mszału Divine Worship, zatytułowany Book of Divine Worship, który stanowił adaptację amerykańskiego wydania Modlitewnika Powszechnego przygotowaną na potrzeby liturgii byłych członków Kościoła Episkopalnego, którzy dokonali konwersji na katolicyzm9 ${ }^{9}$ Jak zauważa Burnham (Divine 160-165), księgę Book of Divine Worship, jako jednego ze spadkobierców Modlitewnika Powszechnego, należy traktować

\footnotetext{
${ }^{8}$ Brand (145-6) wskazuje na pewien brak precyzji takiej terminologii, zważywszy na zróżnicowanie odmian języka angielskiego w XVI wieku.

${ }^{9}$ Wychodząc naprzeciw prośbom konwertytów z anglikanizmu w USA Jan Paweł II wydał regulacje (Pastoral Provision) pozwalające biskupom amerykańskim na tworzenie tzw. parafii personalnych, w których można było sprawować liturgię z zachowaniem pewnych elementów liturgicznej tradycji anglikańskiej. Book of Divine Worship to zaaprobowana przez Rzym księga liturgiczna dla takich parafii personalnych.
} 
jako źródło wtórne dla mszału Ordynariatów. Do pozostałych źródeł wtórnych wypada jeszcze zaliczyć dwa angielskie tłumaczenia tekstów liturgicznych tzw. przedsoborowej mszy św. w rycie rzymskim (sprzed reformy zarządzonej przez Pawła VI), odpowiednio zatytułowane The Anglican Missal (wydania z lat 1921 i 1943) oraz The English Missal (pierwsze wydanie z roku 1912, kolejne w latach 1958 oraz 2001). Tak dobrane źródła zaowocowały księgą liturgiczną, która ma wiele tekstów wspólnych ze współczesnym Mszałem rzymskim (trzecia edycja typiczna), jak również teksty wspólne z „przedsoborowym” Mszatem rzymskim (w tym takie, które nie znajdują się w jego ostatnim przed reformą Pawła VI wydaniu z roku 1962, ale są obecne w jego wcześniejszych wersjach) oraz teksty anglikańskie obce rytowi rzymskiemu, a teraz ,przeszczepione” na grunt liturgii rzymskiej jako „,cenny dar, karmiący wiarę członków Ordynariatu oraz skarb, którym można się dzielić z innymi" (Anglicanorum coetibus 5.III).

Zatem mszał Ordynariatów nie jest w sensie dosłownym angielskim tłumaczeniem Missale Romanum, lecz stanowi autonomiczny tekst współistniejący z angielskim przekładem trzeciej edycji typicznej Mszału rzymskiego (2002), który ujrzał światło dzienne w roku $2010^{10}$, a do użytku liturgicznego wszedł od adwentu 2011 r. $^{11} \mathrm{~W}$ tych fragmentach, które tekst mszału Divine Worship dzieli z tekstami zreformowanego Mszału rzymskiego należałoby raczej mówić o tłumaczeniu „pośrednim”, gdyż dokonano tu kompilacji tekstów, które pierwotnie stanowiły angielskie tłumaczenie tekstów łacińskich. Przy czym, jak zaznaczono wyżej, teksty te pochodzą z różnych źródeł i w sensie chronologicznym przynależą do różnych etapów rozwoju liturgii anglikańskiej.

Przynależność obrzędów sprawowanych według księgi Divine Worship: The Missal do rytu rzymskiego jest zasygnalizowana już na stronie tytułowej sformułowaniem: „zgodnie z rytem rzymskim” (ang. in accordance with the Roman Rite). To zaś oznacza, że mamy do czynienia z trzecią formą rytu rzymskiego będącą współcześnie w użyciu - obok dominującej formy zwyczajnej rytu rzymskiego (tzw. Msza Pawła VI będąca wynikiem reformy posoborowej z lat 60. XX wieku) oraz znacznie rzadziej używanej formy nadzwyczajnej rytu rzymskiego (powszechnie znanej jako tzw. msza trydencka,

\footnotetext{
${ }^{10}$ Wcześniej obowiązywał przekład angielski z roku 1973. Wstępnego porównania dwóch znacząco się różniących angielskich tłumaczeń Mszału Pawła VI dokonano m.in. w pracach Pskita.

${ }^{11}$ Warto odnotować, że polskie thumaczenie trzeciej edycji Missale Romanum (2002) jest nadal w przygotowaniu, a w użytku liturgicznym ciągle stosuje się opublikowany w roku 1986 polski przekład drugiej edycji typicznej.
} 
obecnie najczęściej sprawowanej według mszału promulgowanego w roku 1962 przez Jana XXIII).

Jak zaznaczają liturgiści (Burnham, DiNoia, Lopes), zawarte w Divine Worship teksty obce współczesnemu Mszałowi rzymskiemu - mamy tu na myśli trzy kolejne edycje typiczne tzw. Mszału Pawła VI (1970, 1975, 2000) - przejęte z liturgicznej tradycji anglikańskiej należą do tych elementów anglikańskiego dziedzictwa (ang. Anglican Patrimony), które podtrzymywały wiarę katolicką w kręgach anglo-katolików i stymulowały pragnienie powrotu do pełnej jedności z Rzymem, co znalazło swą kulminację w utworzeniu Ordynariatów.

\section{JĘZYK DIVINE WORSHIP NA TLE \\ ANGIELSZCZYZNY MSZALU RZYMSKIEGO}

Ogólnie rzecz biorąc, język mszału Divine Worship należy uznać za wysoce hieratyczną odmianę angielszczyzny, przynajmniej w świetle koncepcji języka hieratycznego (sakralnego) zawartej w pracach Mohrmann, Crystala czy Langa. Mohrmann (Liturgical) ${ }^{12}$ zwraca uwagę na różnice pomiędzy językiem sakralnym i językiem codziennej komunikacji. Na podstawie swoich badań nad wczesnochrześcijańską greką i łaciną, wskazuje ona także na hieratyczny (sakralny) charakter języka liturgii rzymskiej, który przejawia się w przywiązaniu do starszych form językowych (archaizacja), wprowadzaniu elementów obcych (zapożyczenia z języków „biblijnych”) oraz stosowaniu figur retorycznych typowych dla stylu oratorskiego (dziedzictwo starożytnego stylu rzymskiego). Crystal przekłada to pojęcie języka sakralnego na konkretne właściwości liturgicznej odmiany angielszczyzny, dodając do archaizmów morfo-składniowych i leksykalnych, określone struktury gramatyczne takie, jak nietypowy szyk zdania (łatwo zauważalny w przypadku języka o względnie sztywnym szyku wyrazów, a do takich należy zaliczyć współczesną angielszczyznę), częste formy wołacza czy tryb rozkazujący z podmiotem. Te charakterystyczne formy gramatyczne są oczywiście przynajmniej częściowo wymuszone strukturą językową tradycyjnych modlitw łacińskich w rycie rzymskim.

\footnotetext{
${ }^{12}$ Praca Mohrmann Liturgical Latin: Its Origins and Character (1959) jest od niedawna dostępna w wersji polskiej w thumaczeniu Tomasza Dekerta (Eacina liturgiczna - jej poczatki i charakter. Trzy wyktady) opublikowanym w trzech częściach w kolejnych numerach kwartalnika Christianitas (56-57/2014, 58/2014, 59/2015). Wymienione numery czasopisma w wersji elektronicznej są dostępne na stronie: christianitas.org/archiwa/.
} 
Dodać tu należy, że w podobnym duchu są utrzymane wskazania zawarte w watykańskiej instrukcji Liturgiam authenticam (2001) opracowanej na potrzeby przygotowania przekładów na języki wernakularne trzeciej edycji Missale Romanum (2002). Podkreśla się w tym dokumencie potrzebę wiernego tłumaczenia oryginalnego tekstu łacińskiego (punkt 20), mowa jest też o zastosowaniu środków językowych pozwalających oddać godność i piękno tekstów liturgicznych (punkt 25). Warto tu przywołać zwłaszcza punkt 27 Liturgiam authenticam, który zwraca uwagę na to, że przestrzeganie zawartych w instrukcji zasad ma się przyczynić do wykształcenia „w każdym języku narodowym sakralnego stylu, który mógłby być uznany za język ściśle (proprie) liturgiczny".

Pomimo tego, iż Divine Worship: The Missal (2015) nie stanowi w sensie ścisłym przekładu Mszału Rzymskiego (2002), cechy językowe liturgii Ordynariatów pokażemy zestawiając wybrane teksty z paralelnymi fragmentami z zatwierdzonego do użytku liturgicznego angielskiego przekładu Missale Romanum (trzecia edycja typiczna 2002, przekład angielski 2010), wspierając to również wersją polską z Mszatu Rzymskiego (1986). Ograniczymy się tu do tekstów stanowiących tzw. części stałe Mszy św. Posłużymy się przy tym następującymi skrótami dla poszczególnych ksiąg:

PL 1986 - polskie tłumaczenie dla drugiej edycji typicznej (przekład trzeciej edycji jeszcze się nie ukazał)

ICEL 2010 - angielskie thumaczenie trzeciej edycji Missale Romanum ${ }^{13}$

DW 2015 - Divine Worship: The Missal

Z uwagi na ograniczoną objętość niniejszego artykułu nasza analiza porównawcza dotyczy raptem niewielkiej próbki tekstów, które jednakże ilustrują pewną ogólną tendencję językową. Kluczowe różnice pomiędzy angielskimi wersjami DW 2015 oraz ICEL 2010 - zwykle zaznaczamy podkreśleniem.

Wyższy stopień hieratyzacji języka liturgicznego mszału Ordynariatów względem współczesnego przekładu angielskiego Mszału Rzymskiego przejawia się przede wszystkim na poziomie morfo-składniowym, a w pewnym stopniu również na poziomie leksyki. Można to zauważyć zwłaszcza w obszarze morfologii fleksyjnej, gdyż na wcześniejszych etapach swego rozwoju angielszczyzna była w tym względzie bogatsza, a skoro język Divine

${ }^{13}$ Używamy tu skrótu ICEL (od nazwy komisji przygotowującej przekład angielski: International Commission for English in the Liturgy, dosł. Międzynarodowa Komisja ds. Języka Angielskiego w Liturgii) powszechnie stosowanego w literaturze anglojęzycznej. 
Worship czerpie z dawniejszych tekstów anglikańskich, to nie może dziwić pokaźny zasób starszych - dziś odbieranych jako wysoce archaiczne - form fleksyjnych w tekstach liturgii Ordynariatów (Brand, Burnham Divine). I tak, do różnic o charakterze wręcz systematycznym można zaliczyć kontrast pomiędzy współczesnymi formami zaimków osobowych i dzierżawczych dla drugiej osoby liczby pojedynczej w ICEL 2010 (np. you 'ty/wy, tobie/wam, ciebie/was', your 'twój/wasz') i ich archaicznymi „szekspirowskimi” odpowiednikami w DW 2015 (thou 'ty', thee 'tobie, ciebie', thy lub thine 'twój'). Możemy to zauważyć choćby w kontekście odpowiedzi wiernych na kilkakrotnie powtarzające się w trakcie liturgii mszalnej wezwanie celebransa Pan z wami:

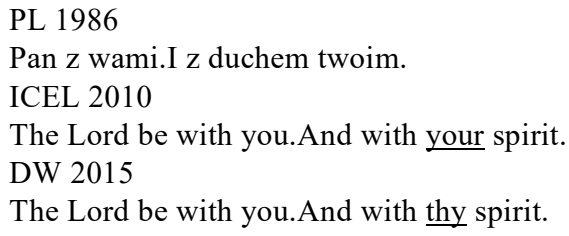

Ta sama opozycja form zaimkowych pojawia się w odpowiedzi wiernych na zapowiedź odczytania Ewangelii i później po zakończeniu czytania:

PL 1986

Chwała Tobie, Panie.

ICEL 2010

Glory to you, O Lord

DW 2015

Glory be to thee, O Lord

PL 1986

Chwała Tobie, Chryste.

ICEL 2010

Praise to you, Lord Jesus Christ

DW 2015

Praise be to thee, O Christ

Użycie archaicznych form zaimkowych thee oraz thy zamiast współczesnych you oraz your ujawnia się także z obfitującym w zaimki hymnie Gloria:

PL 1986

Chwalimy Cię. Błogosławimy Cię. Wielbimy Cię. Wysławiamy Cię. Dzięki Ci składamy, bo wielka jest chwała Twoja.

ICEL 2010 
We praise you, we bless you, we adore you, we glorify you, we give you thanks for your great glory ...

DW 2015

We praise thee, we bless thee, we worship thee, we glorify thee, we give thanks to thee for thy great glory ...

W dalszej części tego samego hymnu, oprócz różnic w obrębie form zaimków, odnotować należy formy czasownikowe takest i sittest z sufiksem dla drugiej osoby liczby pojedynczej czasu teraźniejszego (-est), który zniknął we współczesnej angielszczyźnie. Obecność tego typu form fleksyjnych w mszale Divine Worship przyczynia się do archaicznego tonu tego tekstu:

PL1986

Który gładzisz grzechy świata, zmiłuj się nad nami. Który gładzisz grzechy świata, przyjm błaganie nasze. Który siedzisz po prawicy Ojca, zmiłuj się nad nami.

ICEL 2010

... you take away the sins of the world, have mercy on us; you take away the sins of the world, receive our prayer; you are seated at the right hand of the Father, have mercy on us.

DW 2015

... that takest away the sins of the world, have mercy upon us. Thou that takest away the sins of the world, receive our prayer. Thou that sittest at the right hand of God the Father, have mercy upon us.

W końcowym fragmencie hymnu dodatkowym archaizmem fleksyjnym jest forma teraźniejsza czasownika be dla drugiej osoby liczby pojedynczej „szekspirowskie” art w DW 2015, odpowiadające współczesnemu are w ICEL 2010. W dalszym ciągu można też zaobserwować wcześniej podkreśloną opozycję form zaimkowych:

PL 1986

Albowiem tylko Tyś jest Święty. Tylko Tyś jest Panem. Tylko Tyś Najwyższy ...

ICEL 2010

For you alone are the Holy One, you alone are the Lord, you alone are the Most High ...

DW 2015

For thou only art holy; thou only art the Lord; thou only, O Christ, with the Holy Ghost, art the Most High ...

W Credo w DW 2015 archaiczna forma czasownika shall zastępuje współczesne will. Mamy też do czynienia z archaizmem leksykalnym: żywi, 
współcześnie the living, to $\mathrm{w}$ tekście liturgicznym Ordynariatów the quick. Forma ta nie jest obecnie używana w tym znaczeniu.

\section{PL 1986}

I powtórnie przyjdzie w chwale sądzić żywych i umarłych: a Królestwu Jego nie będzie końca.

ICEL 2010

He will come again in glory to judge the living and the dead, and his kingdom will have no end.

DW 2015

And he shall come again, with glory, to judge both the quick and the dead; whose kingdom shall have no end

Dalej w Credo obserwujemy kolejny archaizm leksykalny, a zarazem przejaw hieratyzacji języka za pomocą zapożyczenia z łaciny. Chodzi tu o użycie rzeczownika remission w sformułowaniu remission of sins 'odpuszczenie grzechów' (łac. ... remissionem peccatorum ...). W ICEL 2010 posłużono się współcześnie $\mathrm{w}$ pełni zrozumiałym rzeczownikiem forgiveness (dosł. przebaczenie, odpuszczenie):

\section{PL 1986}

... na odpuszczenie grzechów

ICEL 2010

... for the forgiveness of sins

DW 2015

... for the remission of sins

Zakończenie Wyznania wiary zawiera też archaiczne formy fleksyjne czasowników proceedeth 'pochodzi' i spake 'mówił':

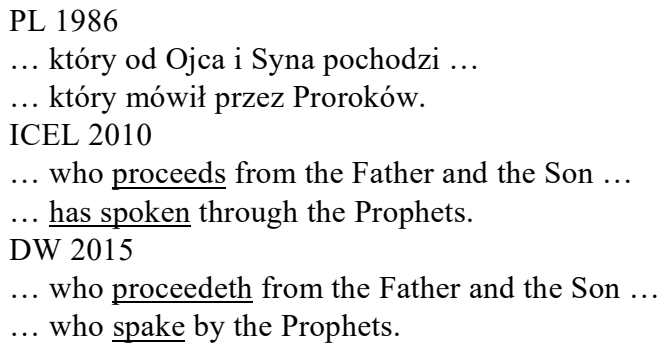

Archaizację leksykalną odnajdujemy też na początku Kanonu Rzymskiego (I Modlitwa Eucharystyczna w zreformowanym Mszale Rzymskim, a zatem również w jego angielskim przekładzie ICEL 2010), gdzie w odpowiedzi wiernych godne to $i$ sprawiedliwe, w DW 2015 występuje archaiczny przy- 
miotnik meet 'słuszny, właściwy'. Odnotować należy też użycie archaicznego przyimka unto zamiast współczesnego to, a także bardziej rozbudowaną (o fragment to do so 'tak czynić') strukturę odpowiedzi wiernych, która odróżnia - znów przez swoje anglikańskie pochodzenie - tekst liturgii Ordynariatów od tekstu zwykle spotykanego w krajach anglojęzycznych w kontekście liturgii rzymsko-katolickiej sprawowanej w tzw. formie zwyczajnej.

PL 1986

Dzięki składajmy Panu, Bogu naszemu.Godne to i sprawiedliwe. ICEL 2010

Let us give thanks to the Lord our God.It is right and just.

DW 2015

Let us give thanks unto the Lord our God.It is meet and right to do so.

\section{ZAKOŃCZENIE}

Powyżej staraliśmy się - siłą rzeczy w dużym skrócie - pokazać podstawowe cechy językowe odmiany liturgii rzymskiej specyficznej dla grup duchownych i wiernych wywodzących się $\mathrm{z}$ anglikanizmu i funkcjonujących w ramach struktury kanonicznej Ordynariatów Personalnych. Przedstawione tu wybrane przykłady tekstów z mszału Divine Worship wskazują na to, że angielszczyzna tych tekstów w znaczący sposób przybliża się ideału języka sakralnego (hieratycznego) nakreślonego w watykańskiej instrukcji Liturgiam authenticam (2001) i omówionego w pracach Mohrmann, Crystala i Langa. Do swego rodzaju paradoksu historii należy zaliczyć fakt, że ta hieratyczna odmiana angielszczyzny wyłania się w obrębie formy rytu rzymskiego, która w głównej mierze stanowi zlepek tekstów anglikańskich, będących pierwotnie tłumaczeniami, a niekiedy adaptacjami, modlitw łacińskich z liturgii katolickiej na potrzeby kultu anglikańskiego. Zatem formy językowe, które wykształciły się poza wspólnotą Kościoła rzymsko-katolickiego (w sensie historyczno-eklezjalnym powstały one w opozycji do Rzymu) stają się teraz źródłem języka liturgicznego w rycie rzymskim sprawowanym w języku narodowym.

Warto również podkreślić, że zarówno pod względem rytualnym, jak i językowym księga liturgiczna Divine Worship, z jednej strony, przyczynia się do wzrostu różnorodności w ramach szeroko pojętego rytu rzymskiego, a z drugiej strony, wzmacnia jedność obrzędową w wymiarze historycznym, gdyż ze względu na swój „hybrydalny” charakter stanowi swego rodzaju pomost pomiędzy starszą formą rytu rzymskiego sprzed reformy przeprowa- 
dzonej po Soborze Watykańskim II (nadzwyczajna forma rytu rzymskiego) i jej nowszą wersją wynikającą z tejże reformy (zwyczajna forma rytu rzymskiego).

\section{BIBLIOGRAFIA}

Benedykt XVI. 2009. Konstytucja apostolska Anglicanorum coetibus, 2009, opoka.org.pl/biblioteka /W/WP/benedykt_xvi/konstytucje/anglicanorum_04112009.html. Dostęp 02.06.2018.

Brand, Clinton A. „Very Members Incorporate: Reflections on the Sacral Language of Divine Worship". Antiphon, nr 19.2, 2015, ss. 132-154.

Burnham, Andrew. „The Contribution of English Litrugical Patrimony to Continuing Renewal in the Roman Rite". Sacred Liturgy. Source and Summit of the Life and Mission of the Church, red. A. Reid, Ignatius Press, 2014, ss. 315-333.

Burnham, Andrew. „Divine Worship: The Missal and 'the Liturgical Books Proper to the Anglican Tradition' (Anglicanorum coetibus, Art. III)". Authentic Liturgical Renewal in Contemporary Perspective, red. U.M. Lang, Bloomsbury T\&T Clark, 2017, ss. 155-170.

Crystal, David. „A liturgical language in a linguistic perspective”. New Blackfriars, 46, 1964, ss. $148-156$.

Crystal, David. „Liturgical language in a sociolinguistic perspective”. Language and the Worship of the Church, red. D. Jasper, R.C.D. Jasper, Macmillan, 1990, ss. 120-146.

DiNoia, Joseph A. „Divine Worship and the Liturgical Vitality of the Church”. Antiphon, nr 19.2, 2015, ss. 109-115.

Divine Worship: The Missal. The Catholic Truth Society, 2015.

Kantyka, Przemysław. „Konstytucja apostolska Benedykta XVI „Anglicanorum coetibus” i jej implikacje dla życia wspólnoty anglikańskiej”. Roczniki Teologii Ekumenicznej, 2(57), 2010, ss. 83-97.

Lang, Uwe M. The voice of the Church at prayer. Reflections on liturgy and language. Ignatius Press, 2012.

Liturgiam authenticam, 2001, opoka.org.p1/biblioteka/W/WR/kongregacje/kkultu/instrukcja_litur giam_28032001.html. Dostęp 07.10.2014.

Lopes, Steven J. „A Missal for the Ordinariates: The Work of the Anglicanae Traditiones Interdicasterial Commission". Antiphon, nr 19.2, 2015, ss. 116-131.

Mohrmann, Christine. Liturgical Latin: Its Origins and Character. Burns and Oates, 1959.

Mohrmann, Christine. „The Ever-Recurring Problem of Language in the Church”. Theology of Renewal, vol. 2. Montreal, 1968, ss. 204-220.

Patterson, Neil. „A Perusal of the History of the Book of Common Prayer”. The Book of Common Prayer: Past, Present and Future, red. Prudence Dailey, Continuum, 2011, ss. 3-14.

Pskit, Wiktor. „Części zmienne Mszy św. w przekładzie: wybrane kolekty w dwóch angielskich wersjach Novus Ordo Missae”. Poznańskie Spotkania Językoznawcze, nr 34, 2017, ss. 125-139.

Pskit, Wiktor. „O języku liturgii rzymskokatolickiej na przykładzie angielskiej wersji Mszału Pawła VI”. Intertekstualność a Stowo Boże, czyli o języku biblijno-religijnym w tekstach 
kultury, część II, red. M.K. Frąckiewicz, A.J. Najda, Instytut Papieża Jana Pawła II, 2018, ss. 179-196.

Składanowski, Marcin. „Anglicanorum coetibus’ wobec problemu anglikańskiej tożsamości”. Roczniki Teologii Ekumenicznej, 2(57), 2010, ss. 99-121.

\section{JĘZYK LITURGICZNY ORDYNARIATÓW PERSONALNYCH \\ DLA BYŁYCH ANGLIKANÓW. ZARYS OGÓLNY}

Streszczenie

Artykuł przedstawia podstawowe cechy językowe mszału Divine Worship (2015) stanowiącego księgę liturgiczną niedawno powołanych Ordynariatów dla byłych anglikanów. Omawia on źródła historyczne tej księgi mszalnej. Charakterystyka językowa Divine Worship jest ukazana za pomocą porównania wybranych tekstów tej księgi z odpowiadającymi im fragmentami z angielskiego przekładu współczesnego Mszału Rzymskiego. Porównanie tych tekstów pozwala zauważyć, iż angielszczyzna liturgii Ordynariatów cechuje się wysokim stopniem hieratyczności (sakralności) w rozumieniu Mohrmann $(1959,1968)$, Crystala $(1964,1990)$ oraz watykańskiej instrukcji Liturgiam authenticam (2001). Ten hieratyczny styl stanowi bezpośredni wkład dziedzictwa anglikańskiego (Anglican Patrimony) do współczesnej liturgii rzymskiej.

Słowa kluczowe: język liturgiczny; Ordynariaty Personalne; Divine Worship; Anglicanorum coetibus; dziedzictwo anglikańskie.

\section{AN OUTLINE OF THE LITURGICAL LANGUAGE \\ OF THE PERSONAL ORDINARIATES FOR FORMER ANGLICANS}

\section{Summary}

The paper presents some basic features of the language of Divine Worship: The Missal (2015), the liturgical book of the recently established Ordinariates for former Anglicans. It discusses the historical sources of the text of the Ordinariate missal. The linguistic characteristics of Divine Worship is shown on the basis of a comparison with corresponding texts in the current English translation of the Roman Missal. The comparison makes it possible to demonstrate that the language of the Ordinariate liturgy is a highly hieratic (sacral) variety of English in the sense of Mohrmann $(1959,1968)$, Crystal $(1964,1990)$ and the Vatican instruction Liturgiam authenticam (2001). The relevant hieratic style is a direct contribution of the Anglican Patrimony to the contemporary Roman liturgy.

Key words: liturgical language; Personal Ordinariates; Divine Worship; Anglicanorum coetibus; Anglican patrimony. 